\section{Analysis Of Lysimetric Parameters Of The Effect Of Chemical And Biological Drugs Against Alfalfa Mosaic Virus}

Khusanov Tokhir Sunnatovich, Phd, Institute Of Microbiology Of The Academy of Sciences Of The Republic Of Uzbekistan

Kadirova Zarifa Nasirovna, Candidate Of Biological Sciences, Institute Of Genetics And Experimental Biology, Academy Of Sciences Of The Republic Of Uzbekistan

Davronov Kodirjon Sotvoldievich, Doctor Of Biological Sciences, Professor, National University, Uzbekistan

\section{Akhmedova Zakhro Rakhmatovna,} Doctor Of Biological Sciences, Professor, Institute Of Microbiology Of The Academy Of Sciences Of The Republic Of Uzbekistan
G Open ACCESS

The American Journal of Agriculture And Biomedical Engineering JULY 2020

Page No.: 25-29

Volume-II Issue-VII

PUBLISHED: 30 JULY 2020 www.usajournalshub.com/inde x.php/tajabe

Copyright: Original content from this work may be used under the terms of the Creative Commons Attribution 4.0 licence.

\title{
Abstract
}

The effect of biological products "Microzyme-2" and "Fosstim-3", developed at the Institute of Microbiology of the Academy of Sciences of the Republic of Uzbekistan, on the alfalfa mosaic virus by the lysimetric method was studied. Chemical preparations "Khimvaks" and "Pharmayod" $(0.02 \%)$ were used as a control. The results showed that the treatment of "Mikrozim-2" (enzyme composition) revealed an average of $19.7 \%$ of plant diseases compared to control. The chemical preparation "Khimvaks" fell on average $68.9 \%$ more than the control. Consequently, the use of biological drugs to control plant viruses leads to a decrease in the incidence of the virus while increasing plant immunity.

Keywords: alfalfa, virus, tomato (Solanum lycopersicum L), bell pepper (Capsicum annuum L), pepper (Capsicum frutescens $L$ ), drug, disease.

\section{Introduction}

In order to obtain high quality and high yields of agricultural crops, their protection from diseases and pests, as well as the widespread use of environmentally friendly biopreparations in the fight against them have a special place $[1,2009 ; 2,2013]$. Today, 
agricultural crops, including more than 1,000 plants and trees, have been found to be significantly affected by various viral diseases, resulting in a significant decrease in their productivity, negatively affecting the amount of beneficial micro and macronutrients in food tracking $[3,2018]$.

The Action Strategy for the Development of the Republic of Uzbekistan sets specific tasks for "The country has adapted to local conditions by further strengthening food security, planting potatoes, vegetables, fodder and oilseeds on vacant lands in exchange for reducing the area under cotton and cereals, as well as planting new intensive orchards and vineyards, creation and introduction of new varieties of crops" [4, 2017].

To implement these issues, it is necessary to develop effective methods of combating various pests of agricultural crops by determining the direct negative impact, damage, pathogen city of pathogenic microorganisms. To this end, the most pressing issue is the phytosanitary control of arable land, in particular, the development of improved methods for early diagnosis of viral diseases [3, 2018; 7, 2008]. Indeed, in recent years, viral diseases have infected a number of agricultural crops grown in the country, including tomatoes, potatoes, bell peppers and a number of vegetable crops, causing serious damage to their yield and quality. According to scientists conducting research in this area, the above-mentioned plants are reported to be infected with the virus that infects the body $[5,2013 ; 6,2006 ; 7,2008 ; 8,2011 ; 9,2013]$.

\section{The Main Findings And Results}

It is known that the study of specific bio-morphological and distribution characteristics of phytopathogenic organisms allows developing measures to combat them.

This work is devoted to the improvement of plant diseases in a lysimetric method, in special containers, for the detection of plant diseases and the development of measures to combat them, by removing the plant and soil from all external environmental factors.

\section{Methods of Research materials}

Experiments with tomato (Solanum lycopersicum L), bell pepper (Capsicum annul L), pepper (Capsicum frutescens $L$ ) plants, 4 different biological drugs before planting young seedlings and chemicals for control - Pharmayod $(0.02 \%)$, with the drug Khimvaks Incubated for 15 minutes with Fosstim-3, Mikrozim-2 bio-preparations for 30 minutes and planted in a special lysimetric. Controlled plants were not treated with drugs. The experiments were performed in 3 repetitions. After 96 hours, the young seedlings were mechanically infected with alfalfa mosaic virus. The drugs used were then sprayed on the plant leaves every 15 days, and the effect of the drugs used on the plants was monitored.

Results obtained and their analysis. Experimental results showed that treatment with a combination of chemical drugs - Farmayod- $0.02 \%$ and Khimvaks, Fosstim-3 and Microzyme -2 was less effective than biological drugs. Treatment of specially infected plants with biological preparations was found to reduce the incidence of disease as a result of the normalization of physiological processes, their positive effect on the immune system, recovery, growth processes relative to control (Fig. 1).

\section{Symptoms of plants grown under lysimetric conditions are given}


THE AMERICAN JOURNAL OF AGRICULTURE AND BIOMEDICALENGINEERING ISSN (e): 2689-1018

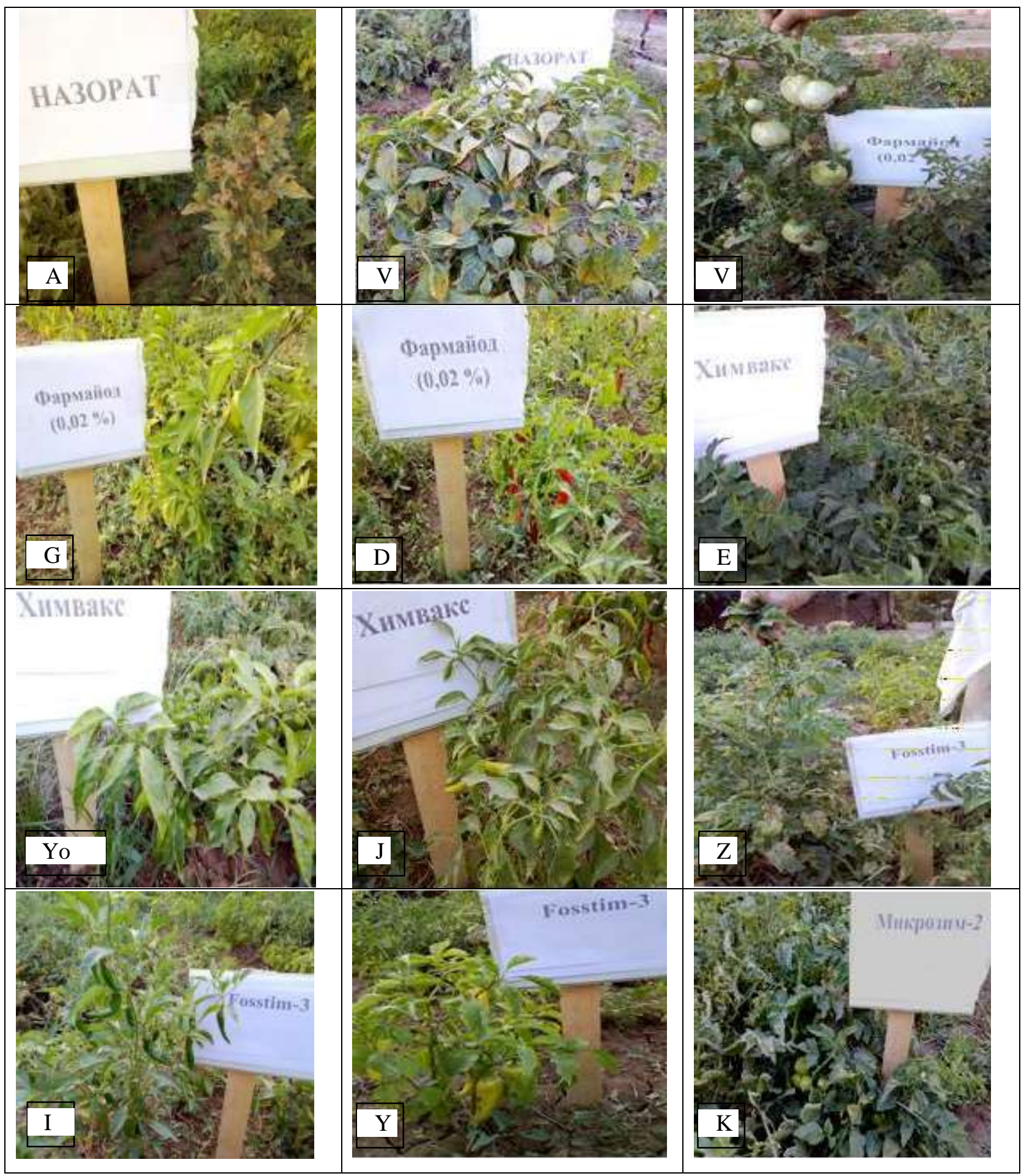




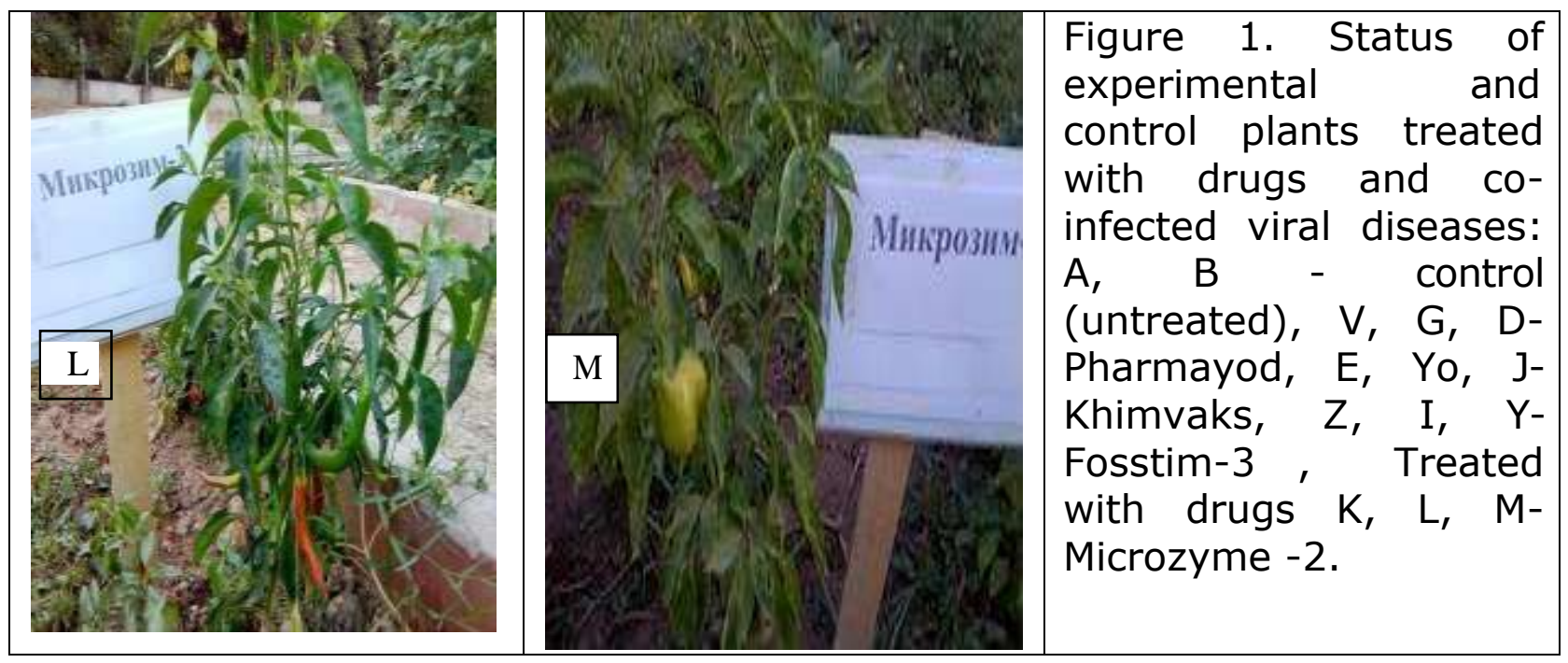

During the experiments, the sap was isolated from the plants treated with the drugs, with which N. Gulutsinosa L. detector plants were mechanically infected and observations were made (Table 1 ). The results showed that the incidence of necrosis decreased in plants treated with biological drugs Mikrozim-2 and Fosstim-3, and in plants treated with chemicals Pharmayod and Khimvaks. Due to the manifestation of the components of biological drugs, biological substances, antibiotics and enzymatic activity, the virus particles were inactivated, partially hydrolyzed, protecting the plants and leading to a decrease in the degree of damage. Compared to chemicals, biological drugs have been shown to reduce the pathogen city of the virus due to its natural origin, chemical composition, rate of assimilation, increased plant immunity, increased resistance, and the ability of the plant to protect itself from it.

Comparative effect of biological and chemical drugs on the amount of virus in plants (number of necrosis)

\begin{tabular}{|l|l|l|l|l|l|l|l|}
\hline \multirow{2}{*}{ № } & \multirow{2}{*}{$\begin{array}{l}\text { Name } \\
\text { drugs }\end{array}$} & \multicolumn{2}{|l|}{ Number of viral necrosis in the examined crops } \\
\cline { 3 - 8 } & Tomato & $\%$ & $\begin{array}{l}\text { Bell } \\
\text { peppers }\end{array}$ & $\%$ & $\begin{array}{l}\text { Chilly } \\
\text { peppers }\end{array}$ & $\%$ \\
\hline 1 & Control & $205,4 \pm 0,07$ & 100 & $153,4 \pm 0,05$ & 100 & $125,2 \pm 0,04$ & 100 \\
\hline 2 & $\begin{array}{l}\text { Microzyme - } \\
2\end{array}$ & $24,4 \pm 0,06$ & 11,9 & $50,1 \pm 0,08$ & 32,7 & $18,2 \pm 0,03$ & 14,54 \\
\hline 3 & Fostium-3 & $57,4 \pm 0,07$ & 27.9 & $30,3 \pm 0,05$ & 19,8 & $22,3 \pm 0,04$ & 17,8 \\
\hline 4 & Khimvaks & $118,4 \pm 0,06$ & 57,6 & $124,3 \pm 0,07$ & 81,03 & $85,5 \pm 0,09$ & 68,3 \\
\hline 5 & $\begin{array}{l}\text { Pharmayod } \\
(0.02 \%)\end{array}$ & $98,2 \pm 0,04$ & 47,8 & $74,3 \pm 0,05$ & 48,4 & $63,2 \pm 0,02$ & 50,5 \\
\hline
\end{tabular}

The results showed that the number of necrosis in various vegetative organs of plants artificially infected with the virus under the influence of Microzyme -2 biopreparation, $11.9 \%$ in tomatoes, $32.7 \%$ in bell peppers and $14.54 \%$ in garlic, remained under the influence of Fosstim-3 while $27.9,19.8$, and $17.8 \%$, respectively. 


\section{Conclusion}

Thus, it was found that the treatment of infected plants with biological drugs, along with changes in certain physiological processes in the plant and strengthening the immune system of the plant, can degrade viral particles that accumulate in the cell. It is also important to note that there is a significant difference between the effects of biological drugs, the sharp difference between the biological drugs Fosstim-3 and Mikrosm-2 and chemical drugs, for their further widespread use in practice. Thus, the applied biopreparations can be used not only in the fight against phytopathogenic microorganisms, but also plant viruses.

\section{References}

[1]. Bayrambekov Sh.B., Korneva O.G. (2009) Biopreparations against potato alternation. Plant protection and quarantine. №. 8. - pp. 30-31.

[2]. M.R. Sharipova, N.P. Balaban, A.M. Mardanova, Ch. Nyamsuren, L.R. Valeeva. (2013) Mechanisms of plant resistance to infections. Scientific notes of Kazan University. Natural Sciences Volume 155. Vol. 4.

[3]. Khusanov Tokhir, Davranov Qodirjan, Vakhabov Abdurasul, Effect of alfalfa mosaic virus on the content of micro and macroelements in alfalfa plants in Uzbekistan., European science review, № 3-4 2018. March-April, - pp. 71-75

[4]. Decree of the President of the Republic of Uzbekistan "On the Strategy of actions for further development of the Republic of Uzbekistan". February 7, 2017, No. PD-4947

[5]. Nguyen Ha Thi Quinh Chang. (2013) Distribution and pathogenesis of viral diseases of tomato in Vietnam and Russia. Abstract of a dissertation for the degree of candidate of biological sciences. - Moscow.

[6]. Xu H, Nie J. (2006) Identification, characterization, and molecular detection of Alfalfa mosaic virus in potato. Phytopathology 96: 1237 - 1242.

[7]. Zitikaitè I, Samuitienè M. (2008) Identification of some properties of Alfalfa mosaic alfamovirus isolated from naturally infected tomato crop. Biologija 54 (2): $83-88$.

[8]. B. He, J. H. Hill, M. R. Hajimorad, Factors to Improve Detection of Alfalfa mosaic virus in Soybean., Accepted for publication 22 July 2011. Published 26 September 2011.

[9]. Mohammed A. AL-Saleh1 and Mahmoud A. Amer., (2013) Biological and Molecular Variability of Alfalfa mosaic virus Affecting Alfalfa Crop in Riyadh Region., Plant Pathol. J. 29(4): - pp. 410-417. 